\title{
Organization Of Independent Work Of Students In An Open Information And Educational Environment
}

Journal Website: http://usajournalshub.c om/index,php/tajssei

\section{Boratova Muxtasam Ganiyevna \\ Senior Lecturer, Faculty Of Natural Sciences, Department Of Biology Teaching Methods, Navoi State Pedagogical Institute, Uzbekistan}

\section{ABSTRACT}

The article describes the content and possibilities of organizing independent work of students in the environment of electronic information education. It covers the methodological forms of organizing students' independent work on the basis of lectures, laboratory, practical, seminars.l

\section{KEYWORDS}

Independent work, information and educational environment, electronic resource, independent test work, lecture, form of organization.

\section{INTRODUCTION}

Modern society requires specialists to independently extract, evaluate, analyze, classify and apply a variety of information in their professional activities, and educational processes in modern universities are increasingly reduced to organizing students' independent work [1], the problem of ensuring the quality of independent work is actualized.

ICT tools are an important tool designed to help the teacher in the practical organization of learning focused on the personality of the learner. So, for example, the use of multimedia 
technologies in a lecture, on the one hand, increases the visibility due to the use of threedimensional graphics, animation, video and sound at the same time, saves time (there is no need to write out abstracts, formulas, diagrams on the board), greatly increases the quality of visualization of the demonstrated material. On the other hand, it helps first-year students to adapt to the requirements of higher education, optimize the process of independent work, in particular, learn how to record lectures. You can develop students' ability to listen to a lecture and rationally record it as follows:

- $\quad$ During the lecture, students compose the content in the form of a synopsis, after the lecture they can revise their abstracts using the teacher's presentation, electronic educational and methodological complex (EEMC), video lecture, links to Internet resources contained in the lecture materials;

- $\quad$ Students are given printed lecture theses, which are supplemented by students during the teacher's speech.

To support students' interest in the material being studied, it is rational to continue the discussion of the lecture issues in the forum organized on the course support site or in a delayed teleconference.

In the first year, to activate the cognitive activity of students, it is advisable to use the following types of lectures: lectureconversation, lecture of a problematic nature, lecture with the use of feedback.

\section{MATERIALS AND METHODS}

The use of ICT in lectures can take various forms, for example, conducting a lecture- conversation using a heuristic approach. In this case, the teacher, with the help of a multimedia presentation, raises a problematic question, which students answer, updating their already existing knowledge of key competencies. Such an interactive presentation of lecture material supports the intrinsic motivation of learning, stimulates the active thinking of students.

In another case, at a lecture with the use of ICT feedback, it can be used in the form of an interactive whiteboard (ACTIVboard) and EUMK. At such a lecture, to activate the work of students after explaining the topic, a short independent work is proposed, containing a number of tasks presented on an interactive board. Students are invited to complete them in notebooks for a certain time. Using the ACTIVboard's Clock feature, you can easily keep track of time for both the teacher and the students. The Reveal tool allows you to cover the part of the screen that shows the solution to this problem. After completing the task, selfcontrol is carried out, for which the solution is shown using the ACTIVboard. This allows students to identify their mistakes and understand what they have not learned from the material studied.

The considered types of organization, independent work of students (IWS) in lectures, contribute to the formation of educational, cognitive, informational competencies and competence of selfimprovement among students.

The practical lesson begins with the entrance control. If the entrance control is not passed, students are invited to repeat the studied material using the theoretical ICOS block. Upon successful passing of the entrance control, the student proceeds to the independent fulfillment of assignments in ICOS using the "Independent work" module. 
The "Independent work" module offers students the conditions for assignments that they perform in a notebook or, using software, enter the received answer into the provided field. If the answer is correct, the student proceeds to a new task, and if the answer is incorrect, then students are offered three-level assistance, developed according to the A.A. method. Andreeva [2].

At the first introduction of an incorrect answer, an indication for a solution is given in the following form: a leading question, an analogy is given, the problem is divided into subtasks, etc. In the case of re-entering an incorrect answer, an indication of what needs to be done is given in a general form. If these instructions are not enough and the wrong answer is again entered, then the program provides an algorithm for solving this problem. Thus, the student independently solves the tasks assigned to him and receives the necessary explanations in case of errors, working at a convenient pace.

After completing all the tasks provided for the topic under study, a report window appears, which indicates the total number of viewed tasks, the number of tasks, the answers to which were given: correct; without a prompt; with hint and wrong. Such an organization of work allows the student to independently learn to solve problems, assess the degree of his preparation, and the teacher - to track the progress of students and, if necessary, correct their training in time, providing individual consultations.

The use of the electronic complex "Independent work" allows you to realize the following methodological goals: increasing motivation in studying, increasing the level of visibility, introducing tasks of various levels of complexity into the educational process.

\section{RESULT AND DISCUSSION}

To conduct self-control in practical classes, the program "Self-control of knowledge" is used. The program "Self-control of knowledge" offers a selection of tasks for each topic, which are recommended for the student to complete. A certain time is allocated for the solution of each task, if necessary, the time can be turned off. The student solves the problem in a notebook or, using software, chooses the correct answer. Each time the program informs about the correctness of the solution to this problem. After completing all tasks, the percentage of correctly completed is reported. Then students are given the opportunity to review the incorrectly solved problems, indicating the correct answers and correct mistakes.

At this stage of training, an interactive whiteboard can be used to explain how to solve problems of independent work that caused difficulties. For example, you can draw a drawing using ACTIVstudio tools such as Straight Line Tool, Square Tool, Circle Tool, Ellipse Tool, Triangle Tool. Then one student is asked to solve the problem in a notebook, and another student is to write the solutions on an interactive whiteboard. For further verification, the ACTIVboard allows for parallel work, in which the teacher, without going up to the board, can make corrections, focus on the aspects that cause difficulties.

Test control, divided into input, current and final, allows systematic feedback with the student, identifying the degree of assimilation of the studied material, gaps.

In the course of a practical lesson, IWS with the use of ICT in the first year helps students to critically assess their knowledge and skills, to 
exercise self-control with the diagnosis of errors; set ourselves the tasks of independent acquisition and deepening of knowledge, which inevitably increases the effectiveness of training and contributes to the disclosure of the individual abilities of each student. Such an organization of the IWS contributes to the formation of communicative competence, further improvement of information and educational and cognitive competencies [3].

Today, the effective organization of the IWS, especially considering that more than $50 \%$ of the studied material in the curriculum is devoted to independent work, is hardly possible without the active use of Internet technologies. First-year students need to be taught the rational search for information on the Internet [4].

To develop the skills of searching for information, hours of independent supervised work (ICR) are used. At the adaptation stage of training, two types of tasks are used for this purpose: "Search tournament" and "Study of the question".

The "Search Tournament" is organized as follows. The teacher preliminarily finds or posts on the network material on a specific issue. Students in the seminar are tasked with finding this material using search engines using keywords. When performing tasks of this type, it is advisable to organize paired work of students, under the supervision of a teacher, with subsequent discussion in the group of the optimal course of searching for information that led to the best result. To consolidate the acquired skills, an assignment is proposed to search and collect, for example, multimedia materials for a given topic (text, illustrations, animation, video, audio). As a result of completing assignments, students learn to search for the necessary information on the
Internet under the guidance and supervision of a teacher.

Thus, the use of Internet resources in the CDS presupposes not only the presence of knowledge of a certain material, but also forms information, communicative competence.

The second type of tasks of the TFR - "Study of the issue" - is carried out as follows. At a lecture, students are asked a question on the topic under study and a detailed plan is proposed, according to which it is necessary to answer it. Using the resources of the Internet, the student must find and analyze the information containing the answer to this question. The result obtained is presented in the form of a report. At the seminar, students present their reports and discuss the results of the assignment during the discussion. If the question was not fully covered, then the teacher, to clarify the answer, offers an annotated list of sites that he developed in advance, using which students find additional information that allows them to fully answer the question.

\section{CONCLUSION}

To organize such an IWS using Internet resources, the teacher has to solve problems such as studying information resources on a given topic, compiling assignments based on the information resources used, choosing criteria for assessing students' independent work, creating tasks for self-control and control.

Thus, in the conditions of further informatization of society and higher education, an increase in the volume and importance of independent work of students, the problem of ensuring its high-quality 
performance in open information and educational environments is actualized.

\section{REFERENCES}

1. Sanko A.M. Factors of efficiency of independent work of students in an institute of higher education. Professional'noe obrazovanie: problemy, podkhody, novatsii: sbornik nauchnykh statei [Professional education: problems, approaches, innovations: collection of scientific articles]. T. I.Rudneva (ed). Samara, Institut analiza ekonomiki goroda i regiona, 2014, pp.80-85 [in Russian].

2. Andreev V.I. Heuristic programming of educational and research activities: method, manual. M : Higher. school, $1981.240 \mathrm{p}$.

3. Ilyin V.V. Pedagogical tools for designing an information resource in a modern university. Dis. on .... cand. ped. sciences. Kaliningrad, 2001.181 p.

4. Ergasheva G.S. Increasing the efficiency of using interactive software in biological education. Monograph. Science and technology, - T.:. 2017 .-- 220 p.

5. Gorach N.N. Upravlenie kachestvom samostoyatel'noi raboty kursantov vuzov MVD Rossii: avtoreferat dis. ... kand. ped nauk [Quality management of independent work of cadets of the Universities of the MVD of Russia: Extended abstract of Candidate's of Education Sciences thesis]. M., 2011, 25 p. [in Russian].

6. Strekalova N.B. Quality of students' independent work. Professional'noe obrazovanie: problemy, podkhody, novatsii: sbornik nauchnykh statei [Professional education: problems, approaches, innovations: collection of scientific articles]. T. I. Rudneva (ed). Samara, Institut analiza ekonomiki goroda i regiona, 2014, pp. 106-114. [in Russian]. 